\title{
HUBUNGAN ANTARA PENGELUARAN UNTUK MINUM DAN POLA KONSUMSI AIR DENGAN STATUS HIDRASI PADA SISWI SMP UNGGULAN BINA INSANI SURABAYA
}

\author{
Yuvienta Ernovitania, Sri Sumarmi \\ Fakultas Kesehatan Masyarakat, Universitas Airlangga \\ Alamat Korespondensi: \\ Yuvienta Ernovitania \\ Email: yuvienta@gmail.com
}

\begin{abstract}
Currently many teenagers only drinking when they are thirsty, while the thirst is a sign of dehydration. Moreover they have another habit, they didn't allocate their money for buying drink and they also didn't bring a tumblr at school. That unhealthy habit can lead dehydration. One of the dehydration's impact was fatigue and lost of focus. The purpose of this research was to analyze the relationship between drink's expense and water consumption patterns with the hydration status at SMP Unggulan Bina Insani Surabaya. This study was an observational study with cross sectional design using simple random sampling technique. The sample was 50 students. The variables were drink's expense, water consumption patterns, and hydration status. This study was conducted at SMP Unggulan Bina Insani Surabaya. Data analysis using spearman/pearson and chi-square test with $\alpha=0.05$. The result of this study showed that most of the student had average drink's expense, less water consumption patterns, and Minimal Dehydration. There was a relationship between drink's expense $(p=0.047)$, and drinking pattern $(p=0.000)$ with hydration status. The conclusion of this study was the two independent variables such drink's expense and water consumption patterns show a significant relationship with hydration status at SMP Unggulan Bina Insani Surabaya. Suggestions for the school was to provide counseling about the definition, signs, impact, and how to prevent dehydration in students in order to avoid the incidence of dehydration.
\end{abstract}

Keywords: drinking pattern, adolescent, hydration status, drink's expense

\begin{abstract}
ABSTRAK
Kebiasaan yang sering dilakukan oleh remaja pada era ini adalah hanya mengonsumsi air saat dirasa haus, sedangkan rasa haus itu sendiri merupakan tanda dehidrasi. Selain itu, remaja saat beraktivitas jarang membawa minum dari rumah dan jarang membeli minum menggunakan uang sakunya saat di sekolah. Kebiasaan tidak sehat tersebut dapat mengakibatkan dehidrasi. Dampak dehidrasi bagi remaja salah satunya dapat mengakibatkan kelelahan sehingga tubuh menjadi lemas dan kehilangan fokus. Tujuan dari penelitian ini adalah untuk menganalisis hubungan pengeluaran untuk minum dan pola konsumsi air dengan status hidrasi pada SMP Unggulan Bina Insani Surabaya. Jenis penelitian ini adalah observasional dengan studi cross sectional dan menggunakan teknik simple random sampling. Jumlah sampel penelitian adalah 50 siswi. Variabel yang diteliti adalah pengeluaran untuk minum, pola konsumsi air, dan status hidrasi. Penelitian dilakukan di SMP Unggulan Bina Insani Surabaya. Analisis data menggunakan uji statistic spearman/pearson dan chi-square dengan nilai $\alpha=0,05$. Hasil penelitian menunjukkan sebagian besar siswi memiliki pengeluaran untuk minum rata antara kategori pengeluaran untuk minum yang tinggi dan rendah, pola konsumsi air yang kurang, dan status hidrasi yang menunjukkan dehidrasi ringan. Selain itu hasil penelitian menggunakan uji statistic spearman/pearson dan chi square menunjukkan ada hubungan yang bermakna antara pengeluaran untuk minum $(\mathrm{p}=0,047)$, dan pola minum $(\mathrm{p}=0,000)$ dengan status hidrasi. Kesimpulan dari penelitian ini adalah dua variabel bebas pada penelitian ini yakni pengeluaran untuk minum dan pola konsumsi air menunjukkan adanya hubungan yang bermakna dengan status hidrasi pada siswi SMP Unggulan Bina
\end{abstract}


Insani Surabaya. Saran untuk pihak sekolah yaitu memberikan penyuluhan terkait pengertian, tanda, dampak, dan cara pencegahan dehidrasi pada siswa agar siswa dapat menghindari kejadian dehidrasi.

Kata kunci: pola minum, remaja, status hidrasi, pengeluaran untuk minum

\section{PENDAHULUAN}

Air merupakan zat gizi yang dibutuhkan oleh tubuh. Air dikelompokkan sebagai zat gizi makro esensial yang memiliki peran untuk katalisator, fasilitator pertumbuhan, pengatur suhu tubuh, pelumas, pengangkut dan alat angkut. Disebut esensial, karena tubuh tidak dapat menghasilkan air untuk memenuhi kebutuhan pada tubuh itu sendiri, sehingga diharuskan mengonsumsi air minum yang cukup (Yuniastuti, 2008).

Manusia lebih mampu bertahan hidup tanpa makanan daripada tanpa air. Tanpa makanan manusia mampu bertahan hidup dalam beberapa minggu, namun tanpa air manusia hanya dapat bertahan hidup dalam beberapa hari (Wardlaw, 2007). Hal tersebut dikarenakan $80 \%$ tubuh manusia mengandung air, sehingga jika manusia kehilangan air maka akan mengakibatkan kematian organ yang berujung kematian total (Muyasaro, 2012). Faktanya, masih banyak masyarakat yang meremehkan konsumsi air minum.

Penelitian THIRST (The Indonesian Regional Hydration Study) di Indonesia menunjukkan bahwa banyak masyarakat yang mengalami dehidrasi ringan pada kelompok remaja berusia 15-18 tahun dan dewasa berusia 25-55 tahun. Hardinsyah (2008) menyatakan bahwa sejumlah 46,1 persen masyarakat Indonesia yang mengalami dehidrasi ringan, kelompok usia remaja merupakan kelompok usia tertinggi yang mengalami dehidrasi ringan yaitu sejumlah 49,5 persen. Persentase masyarakat yang dehidrasi lebih banyak terjadi di dataran rendah, seperti di Jakarta, Surabaya, dan Makassar (Hardinsyah, 2008). Hasil penelitian tersebut diperkuat oleh penelitian lain di Bogor yang menunjukkan 37,3 persen remaja minum kurang dari 8 gelas per hari dan sebesar 24,1 persen remaja asupan cairannya kurang dari 90 persen kebutuhan (Gustam, 2012). Survei serupa juga dilakukan Polytechnic dan Asian Food Information Centre di Singapura menunjukkan bahwa sebagian besar remaja berusia 15-24 tahun belum memenuhi kebutuhan cairan sesuai anjuran dengan minum 8 gelas air per hari. Sedangkan rata-rata perempuan hanya minum 6-7 gelas per hari (Briawan et al ., 2011).

Kebiasaan salah yang sering dilakukan adalah hanya mengonsumsi air minum saat dirasa haus, padahal rasa haus merupakan ciri seseorang sudah mengalami dehidrasi. Dehidrasi terjadi ketika tubuh kehilangan cairan karena pengeluaran air lebih banyak daripada pemasukan, sehingga terjadi ketidakseimbangan cairan di dalam tubuh (Almatsier, 2009). Dehidrasi juga dapat terjadi tanpa disadari pada saat melakukan aktivitas atau karena cuaca panas (D'anci et al ., 2009), dan konsumsi obat diuretik (Schwabe et al ., 2007). Dampak dehidrasi dapat meningkatkan kelelahan sehingga tubuh menjadi lemas dan malas untuk beraktivitas fisik. Jika dehidrasi berlanjut, maka akan meningkatkan risiko penyakit batu ginjal, infeksi saluran kencing, kanker usus besar, konstipasi, obesitas, stroke pembuluh darah otak, dan gangguan yang lainnya (Permanasari, 2010).

Sigit (2012) yang menyatakan bahwa konsumsi cairan pada remaja sebagian besar diperoleh dari minuman yaitu sejumlah 79 persen, dan sisanya sejumlah 21 persen diperoleh dari makanan. Kebutuhan air seseorang salah satunya dipengaruhi oleh jenis kelamin. Wanita lebih sering mengalami dehidrasi dibandingkan pria, karena wanita memiliki pengaruh hormonal yang rentan terhadap kejadian dehidrasi, 
dimana pengaruh hormonal tersebut menyebabkan ketidakseimbangan elektrolit yang mengakibatkan kecenderungan untuk makan lebih tinggi daripada untuk minum (Fauziya, 2011). Hal ini menunjukkan wanita cenderung mengalami kegemukan, Sehingga terdapat hubungan antara kegemukan atau overweight terhadap dehidrasi (Arisman, 2004 dan Fauziya, 2011).

Penelitian Ratnasari (2012) menunjukkan bahwa terdapat hubungan antara wanita yang mengalami dehidrasi dengan jenis minuman yang dikonsumsi. Hal tersebut sejalan dengan penelitian yang dilakukan terhadap pekerja industri pabrik di PT Komatsu Indonesia Jakarta yang menunjukkan bahwa semakin tinggi konsumsi cairan maka nilai berat jenis urin akan semakin rendah, sehingga ada hubungan antara konsumsi cairan dengan status hidrasi (Khairunnisa, 2013). Tujuan dari penelitian ini adalah untuk menganalisis hubungan pengeluaran untuk minum dan pola konsumsi air dengan status hidrasi pada SMP Unggulan Bina Insani Surabaya.

\section{METODE PENELITIAN}

Penelitian ini merupakan penelitian analitik yang bertujuan untuk menganalisis hubungan pengeluaran untuk minum dan pola konsumsi air dengan status hidrasi pada SMP Unggulan Bina Insani Surabaya.

Desain penelitian yang digunakan pada penelitian ini adalah pendekatan kuantitatif dengan studi potong lintang (Cross Sectional) yaitu penelitian yang dilakukan pada saat yang bersamaan antara variabel dependen dan variabel independen. Artinya pada penelitian ini tiap responden hanya diobservasi sekali saja, variabel dependen dan independen diukur pada saat yang bersamaan dan menurut keadaan atau status waktu observasi.

Penelitian ini dilakukan di SMP Unggulan Bina Insani Surabaya. Populasi penelitian ini adalah seluruh siswi SMP Unggulan Bina Insani, menandatangani informed consent, dan bersedia mengikuti penelitian dengan datang saat proses perekrutan (enrollment).

Terdapat dua kriteria inklusi populasi penelitian yakni merupakan siswi aktif kelas VII dan VIII di SMP Unggulan Bina Insani Surabaya tahun ajaran 2016/2017 dan bersedia dilibatkan dalam penelitian sampai selesai dengan menandatangani informed consent.

Sampel penelitian dipilih dengan menggunakan teknik simple random sampling dengan kerangka sampel daftar nama siswi SMP Unggulan Bina Insani. Teknik simple random sampling merupakan pengambilan anggota sampel dari populasi yang dilakukan secara acak tanpa memperhatikan adanya strata yang ada dalam populasi tersebut. Cara simple random sampling yang digunakan adalah dengan mengundi dikarenakan populasinya sedikit. Total siswi yang menjadi responden dalam penelitian ini sebanyak 50 responden.

Variabel dalam penelitian ini terdiri dari variabel terikat yaitu status hidrasi, sedangkan variabel bebas yaitu pola konsumsi air dan pengeluaran untuk minum. Penelitian ini dilakukan dari bulan Januari hingga Juli 2017. Pengumpulan data pengeluaran untuk minum didapat dari hasil jawaban kuesioner yang diisi mandiri oleh responden dan dikategorikan menjadi pengeluaran untuk minum yang tinggi jika $>$ median, sementara dikategorikan rendah jika $\leq$ median. Data pola konsumsi air didapatkan dengan cara wawancara langsung dengan responden menggunakan Semi Quantitative Food Frequency Questionnaire dengan standar kecukupan menggunakan Angka Kecupan Gizi air tahun 2013. Sedangkan untuk data status hidrasi didapatkan dari hasil uji Berat Jenis Urin (BJU) di laboratorium, dengan kategori Well Hydrated jika berat jenis urin 1010 g/dl, Minimal Dehydration jika berat jenis urin $1010 \mathrm{~g} / \mathrm{dl}$ hingga $1020 \mathrm{~g} / \mathrm{dl}$, Significant Dehydration jika berat jenis urin 1021 G/dl hingga 1030 g/dl, dan Seriously Dehydration jika berat jenis urin lebih dari $1030 \mathrm{~g} / \mathrm{dl}$ (Shirreffs, 2003). 
Statistik deskriptif digunakan untuk menjelaskan distribusi karakteristik responden meliputi jumlah pengeluaran untuk minum. Sementara, analisis data dilakukan untuk melihat hubungan antara pola konsumsi air dan pengeluaran untuk minum dengan status hidrasi pada siswi SMP Unggulan SMP Bina Insani Surabaya yang terdiri dari uji chi square dan pearson/spearman. Hubungan antar variabel dapat diketahui dengan membandingkan $p$ dengan $\alpha=0,05$.

\section{HASIL}

Tabel 1. Distribusi Responden Menurut Jumlah Uang Saku yang digunakan untuk Membeli Minum

\begin{tabular}{lcc}
\hline Pengeluaran untuk Minum & $\mathbf{n}$ & $\mathbf{\%}$ \\
\hline Rendah $(\leq 1500$ rupiah) & 25 & 50 \\
Tinggi $(>1500$ rupiah) & 25 & 50 \\
\hline Total & 50 & 100 \\
\hline
\end{tabular}

Pada tabel 1 didapatkan hasil dari 50 responden, 50\% diantaranya atau sebanyak 25 orang memiliki pengeluaran untuk minum yang rendah (kurang dari sama dengan 1500 rupiah), sama juga pada kategori pengeluaran untuk minum yang tinggi (lebih dari 1500 rupiah) juga berjumlah 25 orang. Rata - rata dari jumlah pengeluaran untuk minum adalah 1470 rupiah dan median atau nilai tengahnya adalah 1500. Jumlah pengeluaran untuk minum yang paling kecil adalah 0 rupiah sedangkan jumlah pengeluaran untuk minum yang paling besar adalah 7000 rupiah. Hasil penelitian ini menunjukkan sebagian besar siswi memiliki pengeluaran untuk minum dalam kategori yang sama antara yang tinggi dan rendah.

Tabel 2. Distribusi Responden Menurut Status Hidrasi

\begin{tabular}{lll}
\hline \multicolumn{1}{c}{ Uang Saku Total } & \multicolumn{1}{c}{$\mathbf{n}$} & \multicolumn{1}{c}{$\%$} \\
\hline Rendah $(\leq 10000$ rupiah $)$ & 38 & 76 \\
Tinggi $(>10000$ rupiah $)$ & 12 & 24 \\
\hline Total & 50 & 100 \\
\hline
\end{tabular}

Pada tabel 2 didapatkan hasil dari 50 responden, $76 \%$ diantaranya atau sebanyak 38 orang memiliki uang saku yang rendah (kurang dari sama dengan 10000 rupiah). Sementara sisanya sebesar $24 \%$ atau sekitar 12 orang memiliki uang saku yang tinggi (lebih dari 10000 rupiah). Sedangkan untuk jumlah uang saku total didapatkan rataratanya adalah 11000 rupiah dengan nilai tengah 10000. Jumlah uang saku total yang paling rendah adalah 5000 rupiah sedangkan jumlah uang saku total yang paling tinggi adalah 20000 rupiah. Hasil penelitian ini menunjukkan sebagian besar siswi memiliki uang saku total dalam kategori rendah, yaitu dibawah 10000 rupiah.

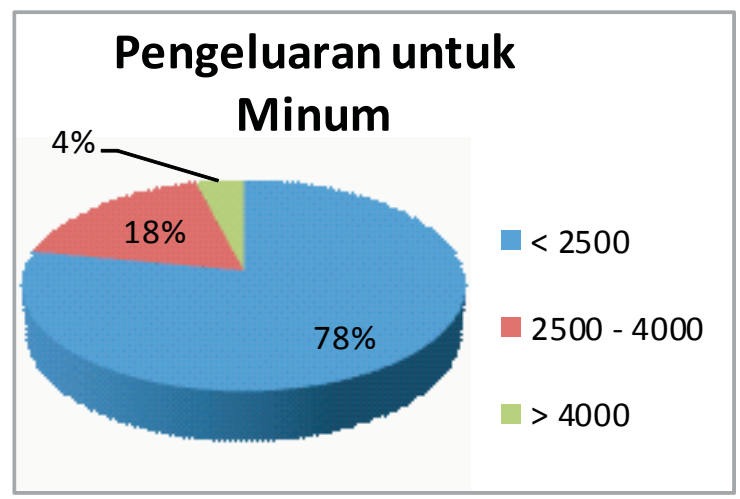

Gambar 1. Distribusi Jumlah Uang Saku yang digunakan untuk Membeli Minum.

Pada gambar 1 menyajikan data pengeluaran untuk minum dari jumlah total uang saku per hari. Diketahui dari 50 responden, sebesar $78 \%$ atau 39 anak menyisihkan kurang dari 2500 rupiah dari jumlah uang sakunya untuk membeli minum. Responden lainnya sebanyak 9 anak (18\%) menyisihkan uang sebanyak 2500 hingga 4000 rupiah untuk membeli minum, sedangkan sisanya sejumlah 2 anak (4\%) menyisihkan lebih dari 4000 rupiah dari total uang saku yang dimiliki untuk membeli minum.

Tabel 3 menunjukkan status hidrasi yang telah dikategorikan menjadi 3 kelompok. Dari 50 responden, sebanyak $48 \%$ atau sekitar 24 anak masuk ke dalam 
Tabel 3. Distribusi Responden Menurut Status Hidrasi

\begin{tabular}{lcc}
\hline \multicolumn{1}{c}{ Status Hidrasi } & n & \% \\
\hline Well Hydrated $(<1010 \mathrm{~g} / \mathrm{dl})$ & 10 & 20 \\
Minimal Dehydration $(1010-1020 \mathrm{~g} / \mathrm{dl})$ & 24 & 48 \\
Significant Dehydration $(1021-1030 \mathrm{~g} / \mathrm{dl})$ & 16 & 32 \\
\hline Total & 50 & 100 \\
\hline
\end{tabular}

kelompok Minimal Dehydration. Sebanyak $20 \%$ atau sekitar 10 anak termasuk dalam kelompok Well Hydrated., sedangkan sisanya sebanyak 32\% atau sekitar 16 anak masuk ke dalam kelompok Significant Dehydration. Hasil penelitian ini menunjukkan sebagian besar siswi mengalami Minimal Dehydration atau disebut dehidrasi ringan.

Tabel 4. Distribusi kecukupan konsumsi air

\begin{tabular}{lcc}
\hline \multicolumn{1}{c}{ Konsumsi Air Minum } & $\mathbf{n}$ & $\mathbf{\%}$ \\
\hline Cukup & 15 & 30 \\
Kurang & 35 & 70 \\
\hline Total & 50 & 100 \\
\hline
\end{tabular}

Pada tabel 4 menunjukkan sebanyak $70 \%$ atau 35 anak memiliki kecukupan konsumsi air yang kurang dan 30\% sisanya sebesar 15 anak memiliki kecukupan konsumsi air yang cukup. Rata-rata dari kecukupan konsumsi air adalah $1656.46 \mathrm{ml}$ dengan standar deviasi 575.14 dan mediannya adalah 1636.07. Jumlah konsumsi air minimum adalah $629.26 \mathrm{ml}$ sedangkan jumlah konsumsi air responden yang maksimum adalah $3163.14 \mathrm{ml}$. Hasil penelitian ini menunjukkan sebagian besar siswi masih kurang dalam memenuhi kebutuhan airnya dalam sehari. Hal ini didapatkan dari data pola konsumsi air dibandingkan dengan Angka Kecukupan Gizi Air, sehingga dapat dikategorikan dalam cukup dan kurang. Hasil penelitian ini menunjukkan sebagian besar siswi memiliki kecukupan pola konsumsi air yang kurang, dibandingkan dengan yang cukup.
Tabel 5 Merupakan tabel yang memuat distribusi konsumsi air setiap harinya menurut jenis minuman dan jumlah konsumsi minum yang ada pada kuesioner. Pada tabel terlihat bahwa konsumsi air putih merupakan jenis minuman yang paling banyak dikonsumsi responden dengan rata-rata $1130.25 \pm 613.52 \mathrm{ml}$ per hari dan dengan frekuensi 120 kali dalam sebulan. Jika dihitung maka konsumsi air putih menyumbang sekitar $57.3 \%$ dari kecukupan konsumsi air minum per harinya. Jumlah minimal air putih yang dikonsumsi adalah $225 \mathrm{ml}$ dan jumlah maksimal adalah $2580 \mathrm{ml}$. Sementara minuman lainnya, tidak semuanya dikonsumsi responden setiap harinya yang dapat dilihat dari jumlah minimal minuman yaitu 0 dengan jumlah maksimal yang bervariasi. Minuman terbanyak kedua yang dikonsumsi oleh responden adalah pop ice dengan rata-rata $147.40 \pm 155.98 \mathrm{ml}$ per hari dan dengan frekuensi 27.6 kali dalam sebulan. Sementara minuman yang paling sedikit dikonsumsi adalah yoghurt dengan rata-rata $3.80 \pm 12.33 \mathrm{ml}$ per hari.

Dari analisis hubungan antara pengeluaran untuk minum dengan status hidrasi diperoleh hasil bahwa status hidrasi yang Well Hydrated banyak terjadi pada kategori jumlah pengeluaran untuk minum yang tinggi sebanyak 7 responden dengan persentase $28 \%$, sementara responden dengan kategori jumlah pengeluaran untuk minum yang rendah hanya 3 responden (12\%). Sedangkan pada status hidrasi yang Significant Dehydration banyak terjadi pada kategori jumlah pengeluaran untuk minum yang rendah sebanyak 11 responden dengan persentase $44 \%$, sementara responden dengan kategori jumlah pengeluaran untuk minum yang tinggi hanya 5 responden $(20 \%)$. Hasil uji statistik korelasi rank spearman menunjukkan bahwa sig (2-tailed) atau $\mathrm{p}=0,047$ dengan koefisien korelasi -0.283 . Dinyatakan bahwa $\mathrm{p}<0,05$ sehingga ada korelasi antara pengeluaran untuk minum dengan status hidrasi pada siswi SMP 
Tabel 5. Distribusi Konsumsi Air Berdasarkan Jenis Minuman

\begin{tabular}{|c|c|c|c|}
\hline Jenis Minuman & Frekuensi (kali/bulan) & $\mathbf{x} \pm \mathbf{s d}$ & Kontribusi Kecukupan Air \\
\hline Yoghurt & 0.9 & $\begin{array}{c}3.80 \pm 12.33 \\
(0-70)\end{array}$ & $0.2 \%$ \\
\hline Es krim & 13.2 & $\begin{array}{c}36.23 \pm 68.89 \\
(0-300)\end{array}$ & $1.8 \%$ \\
\hline Susu & 20.1 & $\begin{array}{c}120.89 \pm 143.39 \\
(0-600)\end{array}$ & $6.2 \%$ \\
\hline Air putih & 120 & $\begin{array}{c}1130.25 \pm 613.52 \\
(225-2580)\end{array}$ & $57.3 \%$ \\
\hline Teh tawar & 0.6 & $\begin{array}{c}6.17 \pm 32.79 \\
(0-225)\end{array}$ & $0.3 \%$ \\
\hline Teh manis & 20.7 & $\begin{array}{c}119.89 \pm 160.90 \\
(0-675)\end{array}$ & $6.1 \%$ \\
\hline Kopi & 2.04 & $\begin{array}{l}6.54 \pm 17.35 \\
\quad(0-80)\end{array}$ & $0.3 \%$ \\
\hline Sari dele & 2.7 & $\begin{array}{c}15.99-40.04 \\
(0-225)\end{array}$ & $0.8 \%$ \\
\hline Air sirup & 4.8 & $\begin{array}{c}27.30 \pm 89.72 \\
(0-580)\end{array}$ & $1.4 \%$ \\
\hline Cola & 1.83 & $\begin{array}{c}10.09 \pm 30.56 \\
(0-185)\end{array}$ & $0.5 \%$ \\
\hline Fanta & 1.8 & $\begin{array}{l}9.39 \pm 29.25 \\
(0-185)\end{array}$ & $0.5 \%$ \\
\hline Sprite & 1.2 & $\begin{array}{c}16.37 \pm 84.98 \\
(0-600)\end{array}$ & $0.8 \%$ \\
\hline Pepsi & 0.57 & $\begin{array}{l}6.15 \pm 25.98 \\
\quad(0-171)\end{array}$ & $0.3 \%$ \\
\hline Pop ice & 27.6 & $\begin{array}{c}147.40 \pm 155.98 \\
(0-675)\end{array}$ & $7.4 \%$ \\
\hline
\end{tabular}

Tabel 6. Analisis hubungan pengeluaran untuk minum dan pola konsumsi air dengan status hidrasi

\begin{tabular}{|c|c|c|c|c|c|}
\hline \multirow[b]{2}{*}{ Variabel } & \multicolumn{3}{|c|}{ Status Hidrasi } & \multirow[b]{2}{*}{$\mathbf{p}$} & \multirow{2}{*}{$\begin{array}{c}\text { Coef. } \\
\text { Correlation }\end{array}$} \\
\hline & $\begin{array}{c}\text { Well } \\
\text { Hydrated }\end{array}$ & $\begin{array}{c}\text { Minimal } \\
\text { Dehydration }\end{array}$ & $\begin{array}{c}\text { Significant } \\
\text { Dehydration }\end{array}$ & & \\
\hline \multicolumn{6}{|c|}{ Pengeluaran Untuk Minum } \\
\hline Rendah & $3(12 \%)$ & $11(44 \%)$ & $11(44 \%)$ & \multirow{2}{*}{0,047} & \multirow{2}{*}{$-0,283$} \\
\hline Tinggi & $7(28 \%)$ & $13(52 \%)$ & $5(20 \%)$ & & \\
\hline \multicolumn{6}{|l|}{ Pola konsumsi air } \\
\hline Kurang & $1(2,9 \%)$ & $18(51,4 \%)$ & $16(45,7 \%)$ & \multirow{2}{*}{0,000} & \multirow{2}{*}{$-0,895$} \\
\hline Cukup & $9(60 \%)$ & $6(40 \%)$ & $0(0 \%)$ & & \\
\hline
\end{tabular}


Unggulan Bina Insani Surabaya. Pada koefisien korelasi menunjukkan arah negative yang artinya semakin tinggi jumlah pengeluaran untuk minum maka nilai berat jenis urin akan semakin rendah atau disebut hidrasi baik.

Dari analisis hubungan antara pola konsumsi air dengan status hidrasi diperoleh hasil bahwa status hidrasi yang Well Hydrated banyak terjadi pada kategori pola minum yang cukup sebanyak 9 responden dengan persentase $60 \%$, sementara responden dengan kategori pola minum yang kurang hanya 1 responden (2.9\%). Sedangkan pada status hidrasi yang Significant Dehydration banyak terjadi pada pola minum yang kurang sebanyak 16 responden dengan persentase $45.7 \%$, sementara pada responden dengan kategori pola minum yang cukup tidak ada yang mengalami Significant Dehydration. Hasil uji statistik korelasi rank spearman menunjukkan bahwa sig (2-tailed) atau $p=0,000$ dengan koefisien korelasi $-0,895$. Dinyatakan bahwa $\mathrm{p}<0.05$ dan koefisien korelasi $-0,895$ sehingga ada korelasi yang tinggi antara pola minum dengan status hidrasi pada siswi SMP Unggulan Bina Insani Surabaya. Pada koefisien korelasi menunjukkan arah negative yang artinya dengan cukupnya pola minum maka nilai berat jenis urin akan semakin rendah atau disebut hidrasi baik.

\section{PEMBAHASAN}

\section{Hubungan Pengeluaran untuk Minum dan Status Hidrasi}

Pada siswa, uang saku merupakan salah satu tanggung jawab dari orang tua terhadap anaknya. Oleh karena itu jumlah uang saku seorang anak dipengaruhi oleh tingkat pendapatan orang tuanya. Semakin besar pendapatan orang tua, maka uang saku yang diberikan pada anak juga semakin besar (Skriptiana, 2009). Uang saku merupakan bagian dari pengalokasian pendapatan keluarga yang diberikan pada anak-anak dalam jangka waktu tertentu untuk memenuhi kebutuhan yang diperlukan (Napitu, 1994).

Hasil analisis hubungan antara pengeluaran untuk minum dan status hidrasi adalah status hidrasi Well Hydrated banyak terdapat pada responden dengan jumlah pengeluaran untuk minum yang tinggi sebesar $28 \%$ sementara pada responden dengan jumlah pengeluaran untuk minum yang rendah hanya $12 \%$. Hasil uji statistik korelasi rank spearman menunjukkan bahwa sig (2-tailed) atau $\mathrm{p}=0,047$ dengan koefisien korelasi -0.283 . Dinyatakan bahwa $\mathrm{p}<0.05$ sehingga ada korelasi antara pengeluaran untuk minum dengan status hidrasi pada siswi SMP Unggulan Bina Insani Surabaya. Pada koefisien korelasi menunjukkan arah negative yang artinya semakin tinggi jumlah pengeluaran untuk minum maka nilai berat jenis urin akan semakin rendah atau disebut hidrasi baik.

Dilihat pada segi persentase, status hidrasi yang Well Hydrated banyak ditemui pada responden dengan jumlah pengeluaran untuk minum yang tinggi. Hal ini terjadi dikarenakan responden dengan uang saku yang tinggi lebih banyak membeli makanan atau minuman yang kadar air nya tinggi, sedangkan responden dengan uang saku yang rendah mengutamakan membeli makanan yang dapat mengenyangkan atau yang banyak mengandung karbohidrat (Winarno, 1993). Pengeluaran untuk minum oleh siswa biasanya digunakan untuk membeli berbagai macam minuman yang diperjualbelikan di kantin sekolah maupun di luar sekolah seperti es blender dan the. Harga minuman ini berkisar antara 1000 hingga 2000 rupiah. Bagi yang memiliki uang saku yang lebih maka bisa menjangkau minuman yang lebih mahal seperti susu kemasan dan botol air putih yang berkisar 3000-5000 rupiah.

Hasil diatas sejalan dengan penelitian Putri (2009) yaitu semakin banyak seseorang memiliki uang, maka semakin baik makanan dan minuman yang diperolehnya. Selain itu juga sesuai dengan hukum Bennet 
yang menyatakan bahwa semakin tinggi pendapatan maka kualitas bahan pangan semakin baik yang dapat dilihat dari perubahan pembelian bahan pangan yang harganya murah menjadi bahan pangan yang harganya lebih mahal dengan kualitas yang lebih baik. Pendapat tersebut juga didukung oleh Alford dan Bogle (1982) yang menyatakan bahwa pendapatan yang tinggi dapat berefek pada kemampuan seseorang untuk membeli makanan dan minuman yang adekuat. Tinggi dan rendahnya uang saku yang diberikan orangtua bergantung dengan tingkat sosio-ekonomi seseorang, dimana status sosio-ekonomi berhubungan dengan asupan air total. Dengan uang saku yang tinggi biasanya lebih banyak mengonsumsi air dari minuman (Drewnowski, 2013).

\section{Hubungan Pola Konsumsi Air dan Status Hidrasi}

Dari analisis hubungan antara pola minum dengan status hidrasi diperoleh hasil bahwa status hidrasi yang Well Hydrated banyak terjadi pada kategori pola minum yang cukup dengan persentase $60 \%$, sementara responden dengan kategori pola minum yang kurang hanya $2.9 \%$. Sedangkan pada status hidrasi yang Significant Dehydration banyak terjadi pada pola minum yang kurang dengan persentase $45.7 \%$, sementara pada responden dengan kategori pola minum yang cukup tidak ada yang mengalami Significant Dehydration. Hasil uji statistik korelasi rank spearman menunjukkan bahwa sig (2-tailed) atau $p=0,000$ dengan koefisien korelasi $-0,895$. Dinyatakan bahwa $\mathrm{p}<0,05$ dan koefisien korelasi $-0,895$ sehingga ada korelasi yang tinggi antara pola minum dengan status hidrasi pada siswi SMP Unggulan Bina Insani Surabaya. Pada koefisien korelasi menunjukkan arah negative yang artinya dengan cukupnya pola minum maka nilai berat jenis urin akan semakin rendah atau disebut hidrasi baik.

Asupan cairan yang tidak memenuhi kebutuhan dikarenakan faktor pola minum.
Hasil diatas sejalan dengan penelitian Shirreffs (2003) yang menyatakan bahwa orang yang mengonsumsi cairan dalam jumlah yang cukup dan sesuai dengan kebutuhan tubuh akan memiliki status hidrasi yang baik, sedangkan orang yang tidak cukup atau kurang dalam mengonsumsi cairan akan mengalami dehidrasi. Hasil penelitian Khairunnisa (2013) di Semarang juga menunjukkan bahwa konsumsi cairan berhubungan negative dengan status hidrasi yang artinya semakin tinggi konsumsi cairan maka akan semakin rendah nilai berat jenis urin yang menunjukkan status hidrasi baik. Penelitian Donna (2015) menunjukkan adanya hubungan konsumsi cairan dengan status hidrasi dan menyatakan bahwa siswa yang konsumsi cairannya kurang memiliki peluang 9.583 kali mengalami dehidrasi dibandingkan dengan siswa yang konsumsi cairannya cukup. Hal ini juga sejalan dengan penelitian yang dilakukan Ratnasari (2012) yang menyatakan bahwa santriwati yang konsumsi airnya kurang banyak ditemukan mengalami dehidrasi.

Pada tabel 5 terlihat bahwa konsumsi air putih merupakan jenis minuman yang paling banyak dikonsumsi responden dengan rata-rata $1130.25 \pm 613.52 \mathrm{ml}$ per hari dan dengan frekuensi 4 kali dalam sehari. Jika dihitung maka konsumsi air putih menyumbang sekitar 57.3\% dari kecukupan konsumsi air minum per harinya. Jumlah minimal air putih yang dikonsumsi adalah $225 \mathrm{ml}$ dan jumlah maksimal adalah $2580 \mathrm{ml}$. Sementara minuman lainnya, tidak semuanya dikonsumsi responden setiap harinya yang dapat dilihat dari jumlah minimal minuman yaitu 0 dengan jumlah maksimal yang bervariasi. Minuman terbanyak kedua yang dikonsumsi oleh responden adalah pop ice dengan rata-rata $147.40 \pm 155.98 \mathrm{ml}$ per hari dan dengan frekuensi 0.9 kali dalam sehari yang artinya mengonsumsi pop ice hampir sekali dalam sehari. Sementara minuman yang paling sedikit dikonsumsi adalah yoghurt dengan rata-rata $3.80 \pm 12.33 \mathrm{ml}$ per hari. 
Hasil diatas sejalan dengan penelitian yang dilakukan Pebriani (2008) dan Paajanen (2007) yang menyatakan bahwa air putih merupakan minuman yang paling baik untuk menjaga tingkat hidrasi, dibandingkan dengan jenis minuman lain seperti kopi atau minuman pemanis lainnya. Kopi dan alcohol akan menyebabkan tubuh kehilangan banyak air, sedangkan pada minuman pemanis lain dapat menambah kalori jika diminum sepanjang hari. Pendapat tersebut juga didukung oleh Briawan (2011) dan Rosmaida (2011) yang menyatakan bahwa air putih merupakan konsumsi yang paling tinggi dibandingkan dengan makanan atau jenis-jenis minuman yang lain.

\section{SIMPULAN}

Kesimpulan dari penelitian ini adalah dua variabel bebas yakni pengeluaran untuk minum dan pola konsumsi air menunjukkan adanya hubungan yang bermakna dengan status hidrasi pada siswi SMP Unggulan Bina Insani Surabaya.

Penelitian ini menunjukkan status hidrasi Well Hydrated banyak terjadi pada responden dengan pengeluaran untuk minum yang tinggi, dibandingkan dengan responden yang pengeluaran untuk minum rendah. Penelitian ini juga menunjukkan status hidrasi yang Well Hydrated banyak terjadi pada kategori pola minum yang cukup, dibandingkan dengan responden dengan kategori pola minum yang kurang. Sedangkan pada status hidrasi yang Significant Dehydration banyak terjadi pada pola minum yang kurang, sementara pada responden dengan kategori pola minum yang cukup tidak ada yang mengalami Significant Dehydration.

Untuk meminimalisir jumlah siswa yang mengalami dehidrasi maka pihak sekolah perlu melakukan edukasi terkait pentingnya kecukupan air minum, tandatanda dehidrasi, dampak dehidrasi, dan cara mencegah dehidrasi agar dapat menambah pengetahuan siswa tentang konsumsi air minum dengan benar. Edukasi mengenai dehidrasi dapat ditambahkan dalam pelajaran olahraga. Kecukupan kebutuhan per hari nya.

Siswa sebaiknya memulai kebiasaan untuk membawa tumblr atau botol minum dari rumah agar dapat memudahkan siswa dalam memperoleh air saat ada di sekolah. Sehingga siswa dapat terhidrasi dengan baik dan terhindar dari risiko dehidrasi dan juga terhindar dari dampak dehidrasi

\section{DAFTAR PUSTAKA}

Alford Bogle. 1982. Nutrition During The Life Cycle. New Jersey: Practice Hall.

Almatsier, S. D. 2009. Prinsip Dasar Ilmu Gizi. Jakarta: Gramedia.

Arisman. 2004. Gizi Dalam Daur Kehidupan : Buku Ajar Ilmu Gizi. Jakarta: Buku Kedokteran EGC.

Briawan, D., Sedayu, T. R. Ekayanti, I. 2011. Kebiasaan Minu Dan Asupan Cairan Remaja Di Perkotaan. Jurnal Gizi Klinik Indonesia, Volume 8, Pp. 36-41.

D'anci, K. E., Arjun V., Jordan H.K., Caroline R.M., \& Holly A.T. 2009. Voluntary Dehydration and Cognitive Performance in Trained College Athletes. Perceptual and Motor Skills, Pp. 251-269.

Donna. 2015. Status Hidrasi Jangka Pendek Berdasarkan Pengukuran PURI (Periksa Urin Sendiri) Menggunakan Grafik Warna Urin pada Remaja Kelas 1 dan 2 di SMAN 63 Jakarta Tahun 2015. Skripsi. Jakarta: Universitas Islam Negeri Syarif Hidayatullah Jakarta.

Drewnowski. 2013. Water and Beverage consumption among Children age 4-13 in the United States. Nutrition Journal.

Fauziyah. 2011. Sehat Dengan Air Putih. Surabaya: Stomata.

Gustam. 2012. Faktor Risiko Pada Remaja Dan Dewasa, S.L.: Departemen Gizi Masyarakat Fakultas Ekologi Manusia IPB.

Hardinsyah, D. 2008. Studi Kebiasaan Minum Dan Hidrasi Pada Remaja Dan Dewasa Di Dua Wilayah Ekologi Yang Berbeda. Pergizi Pangan Indonesia. 
Khairunnisa. 2013. Hubungan Konsumsi Cairan Dengan Status Hidrasi Pada Pekerja Industri Laki-Laki. Semarang: Program Studi Ilmu Gizi Fakultas Kedokteran Universitas Diponegoro.

Muyasaro. 2012. Terapi Air Putih. Jakarta: Dunia Sehat.

Napitu. 1994. Perilaku Jajan di kalangan Siswa SMA di Kota dan Pinggiran Jakarta Kota DKI Jakarta. Tesis. Jakarta.

Paajanen, T. 2007. Health Benefits Of Drinking Water. [Online] AvailableAt: Http://Suite101.Com/Article/ Drinking-Up-Your-Water-A23556.

Pebriani. 2008. Hubungan Kebiasaan Minum Air Putih Dan Faktor Lainnya dengan Asupan Air Total pada Siswa-Siswi SMP Negeri 1 Depok Tahun 2014.

Permanasari, I., 2010. Jangan Abaikan Dehidrasi. [Online] Available At: Http://Keluargasehat.Com/2010/04/08/ J ang a n - A b a i k an - D e hidras i [Diakses 7 Desember 2012].

Putri, A. 2009. Hubungan Antara Asupan Makanan, Aktivitas Di Waktu Senggang, Dan Jenis Kelamin Dengan Status Gizi Lebih Pada Anak-Anak Di Sd Vianney Jakarta Barat Tahun 2009. Skripsi. Depok: FKM UI.

Ratnasari, M. S. 2012. Hubungan Pola Minum Dan Jumlah Konsumsi Cairan Dari Minuman Terhadap Status Dehidrasi Santriwati Usia 16-18 Tahun Di Pondok Pesantren Darunnajah Jakarta Selatan
Tahun 2012. Gizi Indonesia, Volume 35(2), Pp. 120-125.

Rosmaida. 2011. Hubungan Faktor Internal Dan Eksternal Dengan Konsumsi Air Putih Pada Remaja Penghuni Asrama Mahasiswa UI Depok Tahun 2011. Skripsi. Depok: Universitas Indonesia.

Schwabe, L., Gabor S., Ulrich K., Harmut. 2007. Dehydration Does Not Influence Cardiovascular Reactivity To Behavioral Stress In Young Healthy Humans. Clinical Physical Funct Imaging, 27 (5), Pp. 291-297.

Shirreffs. 2003. Markers Of Hydration Status. European Journal Of Clinical Nutrition, 57(Suppl 2), Pp. S6-S9.

Sigit, P. O. \& Dieny, F. F. 2012. Perbedaan Konsumsi Cairan Dan Status Hidrasi Pada Remaja Obesitas Dan Non Obesitas. Journal Of Nutrition College.

Skriptiana, N. R. 2009. Hubungan Antara Pengetahuan Gizi, Teman Sebaya, Media Massa Dan Faktor Lain Dengan Konsumsi Minuman Ringan Berkarbonasi Pada Siswa-Siswi SMP Nurul Fikri Tahun 2009. Skripsi. Depok: FKM UI.

Wardlaw, G. M. \& Jefferey, S. H. 2007. Perspective In Nutrition. 7 Ed. New York: The Mc Graw Hill Companies, Inc.

Winarno. 1993. Pangan Gizi Teknologi dan Konsumen. Jakarta: Gramedia Pustaka Utama.

Yuniastuti. 2008. Gizi Dan Kesehatan. Yogyakarta: Graha Ilmu. 